\title{
FIBP wt Allele
}

National Cancer Institute

\section{Source}

National Cancer Institute. FlBP wt Allele. NCI Thesaurus. Code C51244.

Human FIBP wild-type allele is located in the vicinity of $11 \mathrm{q} 13.1$ and is approximately $5 \mathrm{~kb}$ in length. This allele, which encodes acidic fibroblast growth factor intracellular binding protein, is involved in mitogenesis stimulation, morphological induction and differentiation. 